\title{
Staphylococcus aureus secreted lipases do not inhibit innate
}

\section{immune killing mechanisms [version 1; peer review: 2}

\section{approved, 1 approved with reservations]}

\section{Fiona Sargison, Joana Alves, Amy Pickering (iD, J Ross Fitzgerald (iD}

The Roslin Institute, Edinburgh, UK

V1 First published: 09 Dec 2020, 5:286

https://doi.org/10.12688/wellcomeopenres.16194.1

Latest published: 25 Jun 2021, 5:286

https://doi.org/10.12688/wellcomeopenres.16194.2

\section{Abstract}

Background: Staphylococcus aureus causes an array of diseases in both humans and livestock. Pathogenesis is mediated by a plethora of proteins secreted by $S$. aureus, many of which remain incompletely characterised. For example, S. aureus abundantly secretes two isoforms of the enzyme lipase into the extracellular milieu, where they scavenge upon polymeric triglycerides. It has previously been suggested that lipases may interfere with the function of innate immune cells, such as macrophages and neutrophils, but the impact of lipases on phagocytic killing mechanisms remains unknown. Methods: We employed the epidemic S. aureus clone USA300 strain LAC and its lipase deficient isogenic mutant, along with recombinant lipase proteins, in in vitro experimental infection assays. To determine if lipases can inhibit innate immune killing mechanisms, the bactericidal activity of whole blood, human neutrophils, and macrophages was analysed. In addition, gentamycin protection assays were carried out to examine the influence of lipases on $S$. aureus innate immune cell escape.

Results: There were no differences in the survival of S. aureus USA300 LAC wild type and its lipase-deficient isogenic mutant after incubation with human whole blood or neutrophils. Furthermore, there was no detectable lipase-dependent effect on phagocytosis, intracellular survival, or escape from both human primary and immortalised cell line macrophages, even upon supplementation with exogenous recombinant lipases.

Conclusions: S. aureus lipases do not inhibit bacterial killing mechanisms of human macrophages, neutrophils, or whole blood. These findings broaden our understanding of the interaction of $S$. aureus with the innate immune system.

\section{Keywords}

Staphylococcus, lipase, neutrophils, macrophages, innate immune cells

\section{Open Peer Review \\ Approval Status \\ 12 \\ 23 \\ version 2 \\ (revision) \\ 25 Jun 2021 \\ version 1 \\ 09 Dec 2020
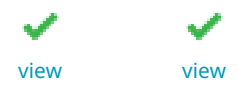 \\ view \\ view \\ 1. Francis Alonzo III, Loyola University Chicago, \\ Maywood, USA \\ 2. Julie A. Morrissey, University of Leicester, Leicester, UK \\ 3. Meera Unnikrishnan ID, University of \\ Warwick, Coventry, UK \\ Any reports and responses or comments on the article can be found at the end of the article.}


Corresponding author: J Ross Fitzgerald (Ross.Fitzgerald@ed.ac.uk)

Author roles: Sargison F: Formal Analysis, Investigation, Methodology, Writing - Original Draft Preparation; Alves J: Conceptualization, Formal Analysis, Supervision, Writing - Review \& Editing; Pickering A: Formal Analysis, Supervision, Writing - Review \& Editing; Fitzgerald JR: Conceptualization, Formal Analysis, Funding Acquisition, Supervision, Writing - Original Draft Preparation, Writing Review \& Editing

Competing interests: No competing interests were disclosed.

Grant information: This study was supported by the Wellcome Trust through a Collaborative award to JRF [201531]. This work was also supported by the Biotechnology and Biology Sciences Research Council institute strategic ISP2 grant (BBS/E/D/20002173 and BBS/E/D/20002174) to JRF.

The funders had no role in study design, data collection and analysis, decision to publish, or preparation of the manuscript.

Copyright: (c) 2020 Sargison F et al. This is an open access article distributed under the terms of the Creative Commons Attribution License, which permits unrestricted use, distribution, and reproduction in any medium, provided the original work is properly cited.

How to cite this article: Sargison F, Alves J, Pickering A and Fitzgerald JR. Staphylococcus aureus secreted lipases do not inhibit innate immune killing mechanisms [version 1; peer review: 2 approved, 1 approved with reservations] Wellcome Open Research 2020, 5 :286 https://doi.org/10.12688/wellcomeopenres.16194.1

First published: 09 Dec 2020, 5:286 https://doi.org/10.12688/wellcomeopenres.16194.1 


\section{Introduction}

The Gram-positive bacterium Staphylococcus aureus is the cause of an array of nosocomial and community-acquired infections. To be a successful pathogen, $S$. aureus must evade killing by the innate immune system which it does via a large number of secreted factors. Within the Staphylococcus genus, a lipaseencoding gene (lipl) is present in at least 12 species, and a second lipase gene is present in $S$. aureus (lip2) and $S$. epidermidis $(g e h D)^{1,2}$. S. aureus lipases are glycerol-ester hydrolases that cleave triglyceride lipids, resulting in the release of glycerol derivatives and free fatty acids. ${ }^{1}$. Lipase 1 has an affinity for short-chain fatty acids, whereas lipase 2 has no bias towards chain length ${ }^{1}$. Transcription of lipase genes is regulated by the accessory gene regulator (agr) two component system, leading to the expression of a pre-pro-lipase precursor that is secreted into the extracellular milieu ${ }^{1,3}$. The catalytic activity of lipases is regulated through downstream processing by the secreted zinc metalloprotease, Aur, which proteolytically cleaves the prepro precursor enzyme resulting in the mature, active form of the enzyme ${ }^{4}$. The activity of the mature lipase is governed by a catalytic triad, which cleaves glycerol-ester bonds through a serine hydrolase mechanism ${ }^{1,2}$. Lipases have been reported to account for approximately $20 \%$ of the total S. aureus secretome, but our understanding of the role of lipases in hostpathogen interactions is limited ${ }^{5}$. It has been shown that $80 \%$ of clinical isolates from both systemic and localised $S$. aureus infections exhibit lipolytic activity, and patients typically test positive for anti-lipase $\mathrm{IgG}$ in serum ${ }^{6,7}$. Lipases have further been attributed to the formation of biofilm, which subsequently confers resistance to toxic polyamines thus promoting bacterial persistence ${ }^{3,8,9}$. Previous studies have further demonstrated that lipases can produce free-fatty acids from host lipid metabolites, such as low-density lipoproteins, which subsequently are incorporated into the lipid moieties of $S$. aureus ${ }^{10}$. The incorporation of lipoprotein particles has been shown to render the bacterium resistant to the antimicrobial drug triclosan, which is commonly used in the treatment of $S$. aureus infection ${ }^{10}$.

In a previous study, human granulocytes were treated with $S$. aureus lipases resulting in the loss of microvilli, projections, and pseudopodia on their surface suggesting a potential impact on phagocytosis or neutrophil extracellular trap (NET) formation $^{11,12}$. More recently, it was demonstrated that lipase 2 interferes with macrophage signalling, which subsequently diminishes the downstream pro-inflammatory response ${ }^{13}$. Specifically, lipase 2 inactivates $S$. aureus secreted lipoproteins, which are a major pattern-associated molecular pattern recognised by Toll-like receptor 2 (TLR2) in response to $S$. aureus infection ${ }^{13}$.

Macrophages are equipped with an array of pathogen recognition receptors and, alongside a role in modulation of cellular signalling, are professional phagocytes that aid in the clearance $S$. aureus $^{14,15}$. However, studies have shown that once entrapped within the macrophage phagolysosome, $S$. aureus can subvert killing mechanisms and persist for several days ${ }^{16,17}$. The subsequent death of the macrophage through membrane blebbing and caspase- 3 activation results in the release of viable bacteria, promoting intra-host dissemination in a Trojan horse-like system $^{14,17,18}$.
Here, we tested the hypothesis that lipases can interfere with the antibacterial activity of whole blood, neutrophils and macrophages. We report that, despite their abundant secretion, lipases have no effect on killing, phagocytosis, intracellular survival or escape of $S$. aureus USA300 LAC.

\section{Methods}

Bacterial growth conditions

$40 \%$ (v/v) glycerol stocks of both a wild type ( $S$. aureus USA300 WT) and an isogenic mutant ( $S$. aureus USA300 Alip1/4lip2) of the CC8 epidemic clone $S$. aureus USA300 LAC generated in a previous study ${ }^{19}$ were stored at $-80^{\circ} \mathrm{C}$. When required, stocks were sub-cultured onto tryptone soy agar (TSA, Oxoid CM131B) or cultured into tryptone soy broth (TSB, Oxoid CM129B) overnight at $37^{\circ} \mathrm{C}$ with agitation (200 rpm). The culture was diluted 1 in 100 in TSB and incubated, until exponential phase $\left(\mathrm{OD}_{600}=0.6-0.8\right)$, as measured using an Amersham Biosciences Ultrospec 2100 pro spectrophotometer. For infection protocols, bacteria were washed in cell culture media and suspended at the required $\mathrm{OD}_{600}$.

Purification of recombinant lipase1 (rLip1) and 2 (rLip2)

Expression plasmid constructs pET156::lip1 or pET156::lip2 ${ }^{19}$ were transformed into ClearColi ${ }^{\circledR}$ BL21 (DE3) electrocompetent cells (Lucigen, 60810-1) by electroporation, according to the manufacturer's instructions. Cells were grown in LB Miller broth (Sigma, L3522-250G) to an $\mathrm{OD}_{600}$ of 0.6 and protein expression was induced with $1 \mathrm{mM}$ isopropyl $\beta$-D-1-thiogalactopyranoside (IPTG, Formedium Ltd, IPTG025) for $4 \mathrm{~h}$ at $37^{\circ} \mathrm{C}$, with agitation $(200 \mathrm{rpm})$, before centrifugation and storage at $-20^{\circ} \mathrm{C}$.

Hexa-histidine tagged proteins were purified by immobilised metal affinity chromatography as described previously ${ }^{19}$. Western blot analysis confirmed the presence of hexa-histidine tagged proteins at $76 \mathrm{kDa}(1$ in 10,000 monoclonal anti-poly His, $\alpha$-diagnostics HISP12-HRP, in $8 \%$ (w/v) skimmed milk (Sigma, 70166-500G) in sterile phosphate buffered saline (PBS)). Primary antibody binding was detected using enhanced luminolbased chemiluminescent (ECL) western blotting substrate (GE Healthcare, RPN2232). For lipopolysaccharide (LPS) removal, $1 \mathrm{ml}$ of Pierce high capacity endotoxin removal resin (Thermo Fisher Scientific, 88271) was used according to the manufacturer's instructions and proteins were quantified using a bicinchoninic acid (BCA) assay (Merck millipore, 71285-3). To analyse recombinant protein lipolysis, a turbiometric assay was used following the methodology outlined previously ${ }^{20}$. For each of the following experiments, $200 \mathrm{nM}$ of recombinant lipase 1 (rLip1) or 2 (rLip2) was used, according to previous estimates of lipase secretion levels by $S$. aureus ${ }^{21}$.

\section{Ethics statement}

Human blood was obtained from healthy volunteers in syringes treated with anticoagulant citrate dextrose. Ethical approval for the collection of blood from anonymous donors was granted by the University of Edinburgh Research Ethics Committee. This study was reviewed by the University Of Edinburgh College Of Medicine Ethics Committee (2009/01) and subsequently renewed by the Lothian Research Ethics Committee 
(11/AL/0168). Written informed consent was received from all volunteers participating in the study.

\section{Bacterial killing by neutrophils}

Neutrophils were purified from human blood using a ficoll gradient. Briefly, $10 \mathrm{ml}$ of $1.077 \mathrm{~g} / \mathrm{mol}$ ficoll paque plus (Fisher, 11778538) was gently layered onto $12 \mathrm{ml}$ of $1.119 \mathrm{~g} / \mathrm{mol}$ Histopaque plus (Sigma, 11191). Fresh human blood was diluted at a 1:1 ratio in $\mathrm{Ca}^{2+}$ and $\mathrm{Mg}^{2+}$ free PBS (Lonza, BE17-515F), then slowly pipetted onto the ficoll gradient prior to centrifugation for $20 \mathrm{~min}$ at $400 \times g$ (without a brake). The neutrophil layer was collected, cells were centrifuged and erythrocytes lysed by osmotic shock. Cells were suspended in RPMI-1640 (Sigma, R5886), 0.05\% (v/v) human serum albumin (Sigma, A9080-10ML) and 1\% (v/v) GlutaMAX (Gibco, 35050-061) prior to use. $50 \mu \mathrm{l}$ of $1.5 \times 10^{5}$ colony forming units (CFU) of $S$. aureus USA300 WT or $S$. aureus USA300 Alip1/ Alip2 bacterial cells were opsonised in $50 \mu \mathrm{l}$ of $10 \%$ autologous human plasma for $15 \mathrm{~min}$ in a 96 well Cellstar U bottomed plate (Greiner BioOne Inc, 650101$)\left(37^{\circ} \mathrm{C}\right)$. Subsequently, $1.5 \times 10^{4}$ neutrophils $(\mathrm{MOI}=10)$ were incubated with the bacteria in the presence or absence of $200 \mathrm{nM}$ rLip1 or rLip2. The plate was shaken at $600 \mathrm{rpm}$ for $30 \mathrm{~min}$ at $37^{\circ} \mathrm{C}$ followed by cell lysis in $0.1 \%$ Triton X-100 (Sigma, P6416-100ML) and plated onto TSA using a modified Miles-Misra technique ${ }^{22}$, whereby $10 \mu \mathrm{l}$ of each 10 -fold bacterial dilution was plated, followed by incubation overnight at $37^{\circ} \mathrm{C}$ and counting of colonies.

\section{Bacterial killing by whole blood}

$75 \mu \mathrm{l}$ of whole blood was infected with $25 \mu \mathrm{l}$ of $1.5 \times 10^{5} \mathrm{CFU}$ of $S$. aureus USA300 WT and S. aureus USA300 Alip1/4lip2 in the presence or absence of $200 \mathrm{nM}$ rLip1, rLip2 or both in a 96 well Cellstar $\mathrm{U}$ bottomed plate for 1,2 and $4 \mathrm{~h}$ at $37^{\circ} \mathrm{C}$, with shaking at $200 \mathrm{rpm}$. Blood was lysed in $0.1 \%(\mathrm{v} / \mathrm{v})$ TritonX-100 (Sigma), viable bacteria counts were determined with $10 \mu \mathrm{l}$ of ten-fold bacterial dilutions in PBS onto TSA using a modified Miles-Misra technique ${ }^{22}$ and incubated overnight at $37^{\circ} \mathrm{C}$.

\section{Isolation of CD14+ monocytes}

Monocytes were isolated from human whole blood following centrifugation at $1200 \times \mathrm{g}$ (no break) for $20 \mathrm{~min}$. Buffy coats were combined and diluted with PBS and subsequently slowly pipetted over $15 \mathrm{ml}$ of $1.199 \mathrm{~g} / \mathrm{mol}$ ficoll paque plus (Sigma). A gradient was generated by centrifugation for $45 \mathrm{~min}$ at $200 \times \mathrm{g}$ (no break), in which the mononuclear cell layer was subsequently removed. Ficoll was removed by centrifugation for $10 \mathrm{~min}$ with $300 \times \mathrm{g}$, and resuspension in PBS. CD14 ${ }^{+}$monocytes were collected using a MAC-LS column as per the manufacturer's instructions (Miltenyi Biotec, 130-042-401).

\section{Macrophage differentiation}

For THP1 differentiation into macrophages, $5 \times 10^{5}$ THP1 cells were seeded in a 96-well Nunc flat bottomed plate in RPMI-1640 (Sigma), 10\% (v/v) heat-inactivated foetal bovine serum (Gibco, 10270-106) and 1\% (v/v) GlutaMAX (Gibco) in the presence of $200 \mathrm{nM}$ phorbol 12-myristate 13-acetate (PMA, VWR P1585-1MG) for $3 \mathrm{~d}$, before being left to rest for $1 \mathrm{~d}$ in media without PMA. For blood monocyte-derived macrophages, $5 \times 10^{5}$ of purified human blood $\mathrm{CD} 14^{+}$cells were incubated for $5 \mathrm{~d}$ in 1:100 dilution of $10^{4} \mathrm{U} / \mathrm{ml}$ recombinant human colony-stimulating factor-1 (hCSF-1, provided by Prof. D. Hume) in media. On the $5^{\text {th }}$ day, cells were topped up with $25 \%$ complete medium containing $3 \times$ the target concentration of hCSF-1 and cells were used at day 7 .

\section{Gentamycin-protection assay}

THP1 macrophages and blood-monocyte derived macrophages were infected at an MOI of 1 with bacteria suspended in fresh media (RPMI-1640 (Sigma), 10\% (v/v) heat-inactivated foetal bovine serum (Gibco) and $1 \%$ (v/v) GlutaMAX (Gibco). Cells were centrifuged at $400 \times \mathrm{g}$ for $5 \mathrm{~min}$ and incubated for $1 \mathrm{~h}$ at $37^{\circ} \mathrm{C}, 5 \% \mathrm{CO}_{2}$. For analysing internalised bacteria (phagocytosis), cells were subsequently incubated with $100 \mu \mathrm{g} / \mathrm{ml}$ gentamycin (Sigma, G1397-10ML) in cRPMI for $30 \mathrm{~min}$. To analyse intracellular survival, cells were subsequently left in $20 \mu \mathrm{g} / \mathrm{ml}$ gentamycin in media and were incubated for a further $24 \mathrm{~h}$ at $37^{\circ} \mathrm{C}, 5 \% \mathrm{CO}_{2}$. Finally, to analyse the escape of intracellular bacteria, cells were incubated for $24 \mathrm{~h}$ in antibiotic-free media at $37^{\circ} \mathrm{C}, 5 \% \mathrm{CO}_{2}$. At each time point, corresponding to the degree of phagocytosis, bacterial intracellular survival, and bacterial escape from the macrophage, cells were lysed in $0.1 \%$ Triton $\mathrm{X}-100$ in PBS for $5 \mathrm{~min}$ at room temperature, and viable cell counting by plating onto TSA as described above.

\section{Statistical methods}

Statistical analysis was performed with GraphPad Prism 8 software (GraphPad, USA).

\section{Results}

Lipases do not inhibit S. aureus survival in human whole blood

Peripheral whole blood contains an array of innate immune components involved in the direct killing of $S$. aureus ${ }^{23-27}$. To evaluate if lipases can promote $S$. aureus survival in blood, human whole blood was incubated with $S$. aureus USA300 LAC (S. aureus USA300 WT) or its isogenic mutant deficient in both lipase 1 and lipase 2 production (S. aureus USA300 Alip1/Alip2) for 1,2 , and $4 \mathrm{~h}$ at $37^{\circ} \mathrm{C}$. Concurrently, S. aureus USA300 Alip1/4lip2 was also incubated with $200 \mathrm{nM}$ of functionally active rLip1 and rLip2 (Extended Figure $1^{28}$ ). There was a 10-fold reduction in the number of recoverable bacteria in the first hour post-infection, followed by a stabilisation of the number of viable bacteria recovered up to $4 \mathrm{~h}$, but there was no difference between the $S$. aureus USA300 WT and the lipase-deficient mutant or strains supplemented with recombinant lipase (Figure $1^{28}$ ). Overall, these data indicate that lipases do not inhibit killing of $S$. aureus USA300 LAC in human whole blood.

\section{S. aureus lipases do not inhibit neutrophil bactericidal activity}

It was previously demonstrated that purified $S$. aureus lipases alter the phenotype of granulocytes, suggesting a possible impact on their function ${ }^{11,12}$. To establish if lipases can inhibit neutrophil killing of $S$. aureus, human neutrophils were isolated from 
fresh whole blood and incubated with opsonised $S$. aureus USA300 WT or $S$. aureus USA300 Alipl/Alip2 for $30 \mathrm{~min}$. As with whole blood, there was a 10 -fold reduction in the number of viable bacteria after incubation with neutrophils, but viability between the $S$. aureus USA300 WT and the lipases-deficient strain did not differ (Figure ${ }^{28}$ ). In addition, neutrophils were incubated with $S$. aureus USA300 Alip1/4lip2 in the presence of exogenous recombinant lipases and there were no differences in the number of recovered viable bacteria between the tested conditions (Figure $2^{28}$ ). Taken together, these data indicate that lipases do not inhibit neutrophil-mediated killing of S. aureus USA300 LAC.

Lipases do not influence phagocytosis, intracellular survival or escape of S. aureus from macrophages

Recently, it was demonstrated that lipolysis of $S$. aureus lipoproteins by lipase 2 facilitated the survival of $S$. aureus through the manipulation of macrophage cellular signalling ${ }^{13}$. In addition, $S$. aureus can interfere with macrophage phagolysosomal killing, enabling intracellular persistence ${ }^{16}$. To examine the capacity for $S$. aureus lipases to influence phagocytosis, intracellular survival, and escape from macrophages, primary human monocytederived macrophages were incubated with $S$. aureus USA300 WT or S. aureus USA300 Alip1/Alip2 in the presence or absence of rLip1 or rLip2 (Figure $3 \mathrm{a}^{28}$ ). Considerable variation in the number of recovered bacteria was observed between technical replicates due to donor variability, but no significant lipase-dependent differences were observed (Figure $3 b^{28}$ ). To further explore the effect of lipases on macrophage function, an immortalised cell line derived from human peripheral blood monocytes (THP1) cells was employed ${ }^{29}$. PMA induces THP1 monocyte differentiation into adherent macrophages which represent a model of human monocyte-derived macrophages ${ }^{30}$. S. aureus USA300 LAC infection of THP1 macrophages exhibited less variation between

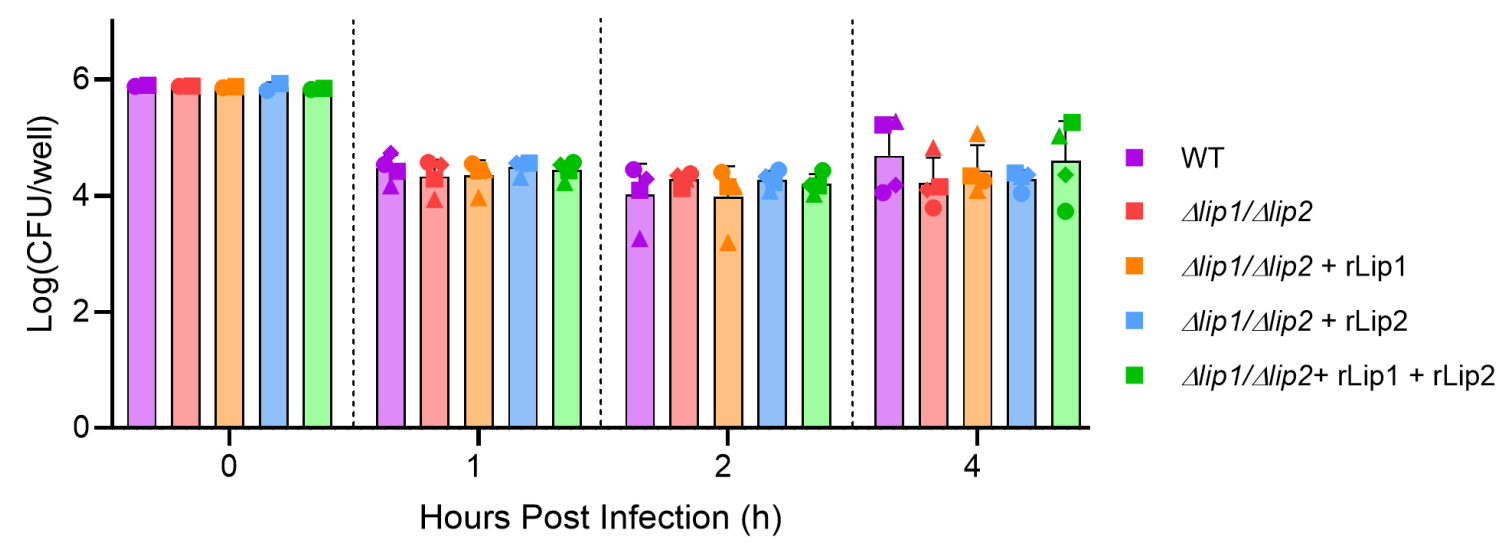

Figure 1. Lipases do not promote survival of $\boldsymbol{S}$. aureus in human whole blood. Human whole blood was collected from healthy donors (each donor represented by a different symbol) and incubated with S. aureus USA300 WT or S. aureus USA300 Alip1/Alip2, alongside S. aureus USA300 $\Delta$ lip1/Alip2 supplemented with $200 \mathrm{nM}$ rLip1 and/or rLip2 for 0, 1, 2 and $4 \mathrm{~h}$, at $37^{\circ} \mathrm{C}$ (with agitation). Each symbol represents the average of technical triplicates. Two-way ANOVA with Tukey's multiple comparisons. Bars show mean + SD, n=4.

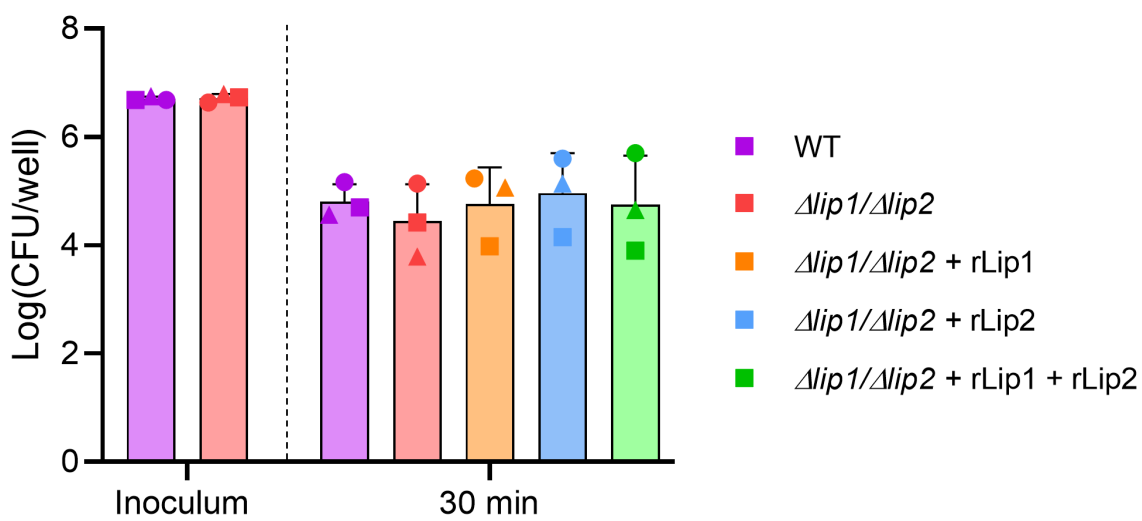

Figure 2. Lipases do not inhibit human neutrophil bactericidal activity. Human neutrophils were isolated from healthy donors (each donor represented by a different symbol) and incubated with plasma opsonised S. aureus USA300 WT or S. aureus USA300 $\Delta$ lip1/4lip2 at an $\mathrm{MOI}$ of 10, in the presence or absence of $200 \mathrm{nM}$ rLip1 and/or rLip2 for $30 \mathrm{~min}$ at $37^{\circ} \mathrm{C}$ (with vigorous agitation). Each symbol represents the mean of 5 technical replicates for an individual donor. One-way ANOVA with Tukey's multiple comparisons. Bars show mean + SD, $n=3$. 
(a)

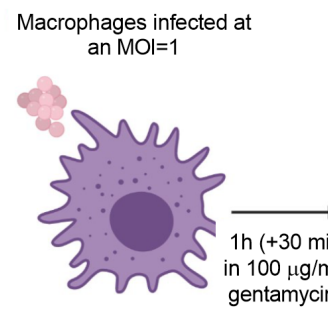

Phagocytosis

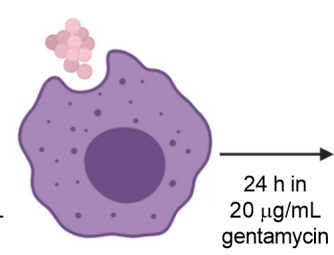

Intracellular

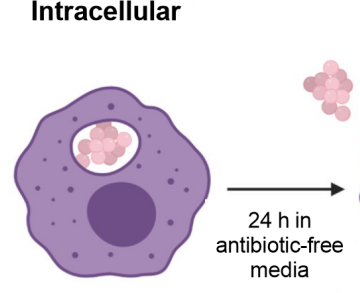

Escape

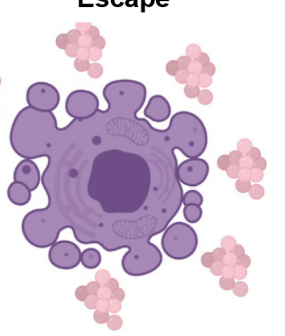

(b)

Primary Blood Monocyte derived Macrophages

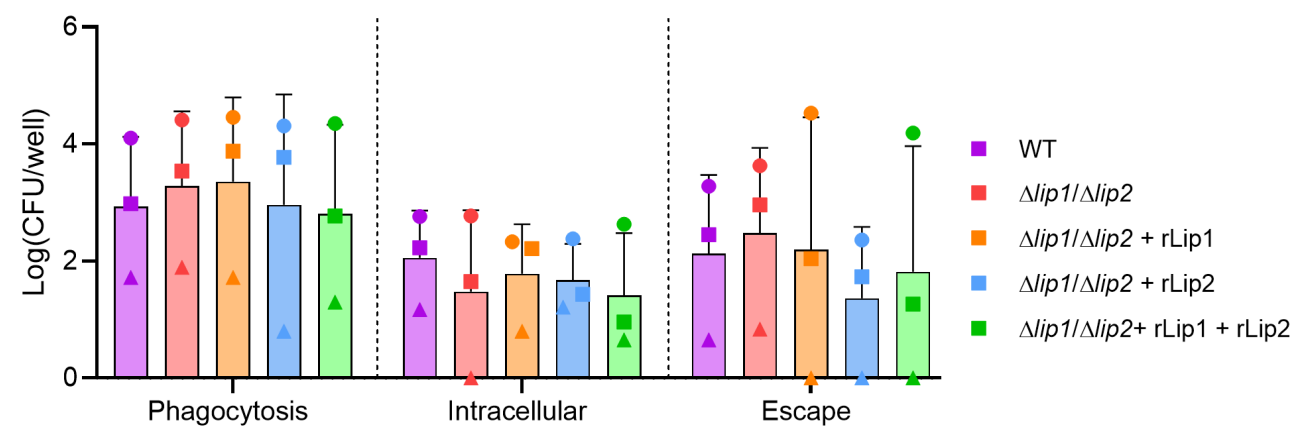

(c)

\section{THP1 derived Macrophages}

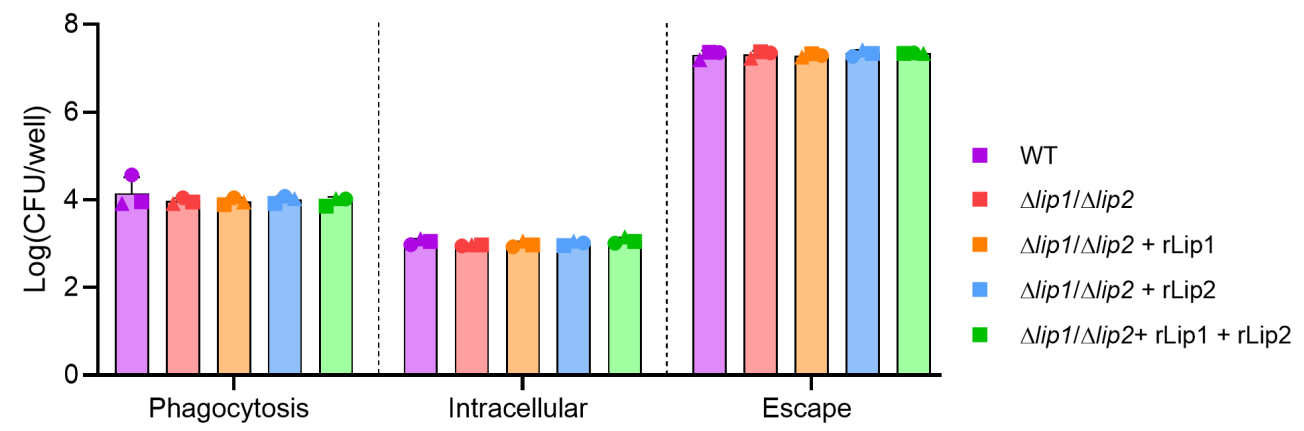

Figure 3. Lipases do not affect bacterial survival in human blood monocyte or THP1 derived macrophages. (a) Schematic of the assay used to analyse the phagocytosis, intracellular proliferation and escape of S. aureus from within macrophages. (b) Primary macrophages were differentiated from human blood monocytes isolated from 3 different healthy donors (represented by different symbols)

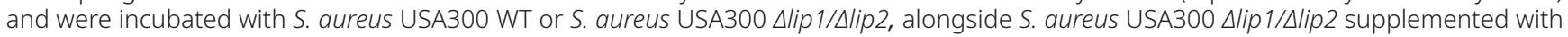
$200 \mathrm{nM}$ rLip1 and/or rLip2 as per the schematic in Fig 4a, followed by plating and viable counting. (c) THP1 macrophages were incubated

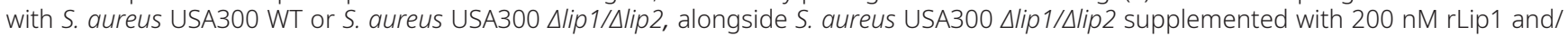
or rLip2 following the schematic in Fig 4a. CFU analysis of phagocytosis, $24 \mathrm{~h}$ intracellular survival and $24 \mathrm{~h}$ escape was quantified for 3 technical replicates. Paired data was analysed using a two-way ANOVA, Tukey's multiple comparisons. Bars show mean + SD, $n=3$.

replicates when compared to primary cultures but no lipasedependent differences in the number of bacteria recovered was observed (Figure $3 \mathrm{c}^{28}$ ). Together, these data indicate that lipases do not affect phagocytosis, survival or escape of $S$. aureus from human macrophages.

\section{Discussion}

The importance of neutrophils in the initial response to $S$. aureus infection is well established ${ }^{24,31}$. Previously, Rollof et al., demonstrated, using scanning electron microscopy, that supernatant-purified $S$. aureus lipases altered granulocyte 
morphology by denuding surface projections ${ }^{11}$. As neutrophil phagocytosis is reliant on pseudopod extensions for ingesting bacteria, it was hypothesised that this phenotype could inhibit bactericidal activity ${ }^{24}$. Furthermore, the release of extracellular DNA into the environment, through NETosis, could be impacted by lipase-mediated changes to the cellular membrane which could influence bacterial killing.

Here, we demonstrate that lipases do not inhibit direct killing of $S$. aureus mediated by human neutrophils, macrophages or whole blood in vitro. The findings are consistent with the findings of Nguyen et al., who did not observe any differences in bacterial burden in the heart and liver in an in vivo murine sepsis model $24 \mathrm{~h}$ after infection with $S$. aureus USA300 WT LAC or an isogenic lipase-deficient mutant ${ }^{3}$. These data suggest that lipases do not interfere with the initial clearance of $S$. aureus from the blood.

A recent study by Chen et al., reported that lipases have no direct effect on initial bacterial clearance in the early stages of infection. However they demonstrated that after $48 \mathrm{~h}$, there was an indirect effect of lipase 2 resulting in reduced pro-inflammatory cytokine release by macrophages ${ }^{13}$. The authors found that $S$. aureus lipase 2 mediates cleavage of $S$. aureus lipoproteins, which are well characterised TLR2 ligands, resulting in increased bacterial burden by thwarting macrophage responses.

Previously it has been shown that $S$. aureus virulence factors regulated by the agr quorum-sensing system are required for survival and escape of $S$. aureus from macrophages, including the zinc metalloprotease Aur which is responsible for the downstream activation of the catalytically active lipases ${ }^{16,32,33}$. Here, we report that the agr-regulated lipases do not influence the survival of $S$. aureus in human monocyte-derived macrophages, although considerable donor specific variation was observed with primary cells. Data obtained using the THP1 macrophage cell line further support the finding that $S$. aureus lipases do not affect phagocytosis, intracellular survival or escape of $S$. aureus from human macrophages. The lack of an observable effect of lipases may reflect the fact that bacterial capture by macrophages is dependent on dynamic actin-rich protrusions, with negligible involvement of triglyceride lipids in the process ${ }^{34}$.

\section{Conclusion}

Overall, we report that $S$. aureus lipases do not directly impact on the killing mechanisms of neutrophils and macrophages. These data add to our understanding of $S$. aureus interactions with the innate immune system and the role of lipases in the pathogenesis of $S$. aureus disease.

\section{Data availability}

\section{Underlying data}

Edinburgh Datashare: Staphylococcus aureus secreted lipases do not inhibit innate immune killing mechanisms: Extended Figure 1. https://doi.org/10.7488/ds/288128

This project contains the following underlying data:

- Validation of rLip1 and rLip2.xlsx (ClarioSTAR (BMG Labtech) readouts of both rLip1 and rLip2, alongside $400 \mathrm{nM}$ BSA. Absorbance was measured at $\mathrm{OD}_{495}$ every $5 \mathrm{~min}$ for $20 \mathrm{~h}$. Each experiment contained three technical repeats, $n=3$ )

- Recombinant lipases Western blot, raw-unedited image. jpg (Raw gel image for Western presented in Extended Figure 1)

\section{Extended data}

Edinburgh Datashare: Staphylococcus aureus secreted lipases do not inhibit innate immune killing mechanisms: Extended Figure 1. https://doi.org/10.7488/ds/288128

\section{- Extended Figure 1.docx}

Extended Figure 1: Functional characterisation of purified recombinant $S$. aureus lipase 1 and 2. (a) Purification of recombinant lipase 1 and 2 was analysed using western blot, in which bands present at $76 \mathrm{kDa}$ indicated the correct protein elution (detected by hexa-his tag, $\alpha$-diagnostics HISP12-HRP). Page-Ruler ladder (furthest left well) shows the visible protein marker at $75 \mathrm{kDa}$. Measurement of lipolytic activity of recombinant protein 1 (rLip1) (b) and 2 (rLip2) (c). It was observed that both lipase 1 and 2 were functionally active enzymes which were able to cleave Tween-20 over a broad scope of concentrations. Indeed, it was also observed that lipase 2 was much more kinetically active in comparison to lipase 1, which could be attributed to its broader substrate range. Two-way ANOVA, Dunnets Multiple Comparisons against the BSA negative control, $\alpha=0.05$, $* * * * \mathrm{p}<0.001$. Each point shows mean $+\mathrm{SD}$ (Data represent a representative experiment, from three independent experiments).

Data are available under the terms of the Creative Commons Attribution 4.0 International license (CC-BY 4.0).

\section{Acknowledgments}

The authors would like to thank Dr Kenneth Baillie, Dr Clark Russell and Dr Sara Clohisey for blood draws which were essential for this study. 
1. Rosenstein R, Götz F: Staphylococcal lipases: Biochemical and molecular characterization. Biochimie. 2000; 82(11): 1005-1014. PubMed Abstract | Publisher Full Text

2. Götz F, Verheij HM, Rosenstein R: Staphylococcal lipases: molecular characterisation, secretion, and processing. Chem Phys Lipids. 1998; 93(1-2): $15-25$.

PubMed Abstract | Publisher Full Text

3. Nguyen MT, Luqman A, Bitschar K, et al.: Staphylococcal (phospho)lipases promote biofilm formation and host cell invasion. Int J Med Microbiol. 2018; 308(6): 653-663.

PubMed Abstract | Publisher Full Text

4. Cadieux B, Vijayakumaran V, Bernards MA, et al.: Role of Lipase from Community-Associated Methicillin-Resistant Staphylococcus aureus Strain USA300 in Hydrolyzing Triglycerides into Growth-Inhibitory Free Fatty Acids. J Bacteriol. 2014; 196(23): 4044-4056.

PubMed Abstract | Publisher Full Text | Free Full Text

5. Busche T, Hillion M, Loi VV, et al.: Comparative Secretome Analyses of Human and Zoonotic Staphylococcus aureus Isolates CC8, CC22, and CC398. Mol Cell Proteomics. 2018; 17(12): 2412-2433.

PubMed Abstract | Publisher Full Text | Free Full Text

6. Rollof J, Hedström SA, Nilsson-Ehle P: Lipolytic activity of Staphylococcus aureus strains from disseminated and localized infections. Acta Pathol Microbiol Immunol Scand B. 1987; 95(2): 109-113.

PubMed Abstract | Publisher Full Text

7. Christensson B, Fehrenbach FJ, Hedstrom SA: A New Serological Assay for Staphylococcus aureus Infections: Detection of IgG Antibodies to S. aureus Lipase with an Enzyme-Linked Immunosorbent Assay. J Infect Dis. 1985; 152(2): 286-292.

PubMed Abstract | Publisher Full Text

8. Hu C, Xiong $N$, Zhang $Y$, et al.: Functional characterization of lipase in the pathogenesis of Staphylococcus aureus. Biochem Biophys Res Commun. 2012; 419(4): 617-620.

PubMed Abstract | Publisher Full Text

9. Xiong $\mathrm{N}, \mathrm{Hu} \mathrm{C}$, Zhang $\mathrm{Y}$, et al.: Interaction of sortase $\mathbf{A}$ and lipase $\mathbf{2}$ in the inhibition of Staphylococcus aureus biofilm formation. Arch Microbiol. 2009; 191(12): 879-884.

PubMed Abstract | Publisher Full Text

10. Delekta PC, Shook JC, Lydic TA, et al.: Staphylococcus aureus Utilizes HostDerived Lipoprotein Particles as Sources of Fatty Acids. J Bacteriol. 2018. 200(11): e00728-17.

PubMed Abstract | Publisher Full Text | Free Full Text

11. Rollof J, Braconier JH, Söderström C, et al.: Interference of Staphylococcus aureus lipase with human granulocyte function. Eur J Clin Microbiol Infect Dis. 1988: 7(4): 505-10. PubMed Abstract | Publisher Full Text

12. Rollof $\mathrm{J}$, Vinge $\mathrm{E}$, Nilsson-Ehlet $\mathrm{P}$, et al.: Aggregation of human granulocytes by Staphylococcus aureus lipase. J Med Microbiol. 1992; 36(1): 52-55. PubMed Abstract | Publisher Full Text

13. Chen $X$, Alonzo F 3rd: Bacterial lipolysis of immune-activating ligands promotes evasion of innate defenses. Proc Natl Acad Sci U S A. 2019; 116(9): 3764-3773.

PubMed Abstract | Publisher Full Text | Free Full Text

14. Flannagan RS, Heit B, Heinrichs DE: Intracellular replication of Staphylococcus aureus in mature phagolysosomes in macrophages precedes host cell death, and bacterial escape and dissemination. Cell Microbiol. 2016; 18(4): 514-535. PubMed Abstract | Publisher Full Text

15. Koymans KJ, Feitsma LJ, Brondijk THC, et al.: Structural basis for inhibition of TLR2 by staphylococcal superantigen-like protein $\mathbf{3}$ (SSL3). Proc Natl Acad SC USA. 2015; 112(35): 11018-11023.

PubMed Abstract | Publisher Full Text | Free Full Text

16. Kubica M, Guzik, K, Koziel J, et al.: A Potential New Pathway for Staphylococcus aureus Dissemination: The Silent Survival of S. aureus Phagocytosed by Human Monocyte-Derived Macrophages. PLoS One. 2008; 3(1): e1409.

PubMed Abstract | Publisher Full Text | Free Full Text
17. Koziel J, Maciag-Gudowska A, Mikolajczyk T, et al.: Phagocytosis of Staphylococcus aureus by macrophages exerts cytoprotective effects manifested by the upregulation of antiapoptotic factors. PLoS One. 2009; 4(4): e5210.

PubMed Abstract | Publisher Full Text | Free Full Text

18. Lacoma $A$, Cano V, Moranta $D$, et al.: Investigating intracellular persistence of Staphylococcus aureus within a murine alveolar macrophage cell line. Virulence. 2017; 8(8): 1761-1775.

PubMed Abstract | Publisher Full Text | Free Full Text

19. Goncheva MI, Conceicao C, Tuffs SW, et al.: Staphylococcus aureus Lipase 1 Enhances Influenza A Virus Replication. mBio. 2020; 11(4): e00975-20. PubMed Abstract | Publisher Full Text | Free Full Text

20. von Tigerstrom RG, Stelmaschuk S: The use of Tween $\mathbf{2 0}$ in a sensitive turbidimetric assay of lipolytic enzymes. Can J Microbiol. 1989; 35(4): 511-514. PubMed Abstract | Publisher Full Text

21. Goncheva MI: The role of bacterial secreted proteins during influenza a virus-staphylococcus aureus co-infection - ProQuest. 2017. Reference Source

22. Miles AA, Misra SS, Irwin JO: The estimation of the bactericidal power of the blood. J Hyg (Lond). 1938; 38(6): 732-749.

PubMed Abstract | Publisher Full Text | Free Full Text

23. Thurlow LR, Hanke ML, Fritz T, et al.: Staphylococcus aureus Biofilms Prevent Macrophage Phagocytosis and Attenuate Inflammation In Vivo. J Immuno. 2011; 186(11): 6585-6596.

PubMed Abstract | Publisher Full Text | Free Full Text

24. van Kessel KPM, Bestebroer J, van Strijp JAG: Neutrophil-Mediated Phagocytosis of Staphylococcus aureus. Front Immunol. 2014; 5: 467. PubMed Abstract | Publisher Full Text | Free Full Text

25. Johannessen M, Sollid JE, Hanssen AM: Host- and microbe determinants that may influence the success of $\mathbf{S}$. aureus colonization. Front Cell Infect Microbiol. 2012; 2: 56.

PubMed Abstract | Publisher Full Text | Free Full Text

26. Cunnion KM, Benjamin DKJr, Hester CG, et al.: Role of complement receptors 1 and 2 (CD35 and CD21), C3, C4, and C5 in survival by mice of staphylococcus aureus bacteremia. J Lab Clin Med. 2004; 143(6): 358-365. PubMed Abstract | Publisher Full Text

27. Brown AF, Murphy AG, Lalor SJ, et al.: Memory Th1 Cells Are Protective in Invasive Staphylococcus aureus Infection. PLoS Pathog. 2015; 11(11): e1005226.

PubMed Abstract | Publisher Full Text | Free Full Text

28. Fiona S, Joana A, Amy CP, et al:: Staphylococcus aureus secreted lipases do not inhibit innate immune killing mechanisms: Extended Figure 1. [dataset] University of Edinburgh. College of Medicine and Veterinary Medicine. Roslin Institute. Infection and Immunity. 2020 http://www,doi.org/10.7488/ds/2881

29. Bosshart $\mathrm{H}$, Heinzelmann M: THP-1 cells as a model for human monocytes. Ann Transl Med. 2016; 4(21): 438 PubMed Abstract | Publisher Full Text | Free Full Text

30. Chanput W, Mes Jl, Wichers HJ: THP-1 cell line: An in vitro cell model for immune modulation approach. Int Immunopharmacol. 2014; 23(1): 37-45. PubMed Abstract | Publisher Full Text

31. Spaan AN, Surewaard BGJ, Nijland R, et al: Neutrophils Versus Staphylococcus aureus: A Biological Tug of War. Annu Rev Microbiol. 2013; 67: 629-650. PubMed Abstract | Publisher Full Text

32. Münzenmayer L, Geiger T, Daiber E, et al.: Influence of Sae-regulated and Agr-regulated factors on the escape of Staphylococcus aureus from human macrophages. Cell Microbiol. 2016; 18(8): 1172-1183. PubMed Abstract | Publisher Full Text

33. Gor V, Takemura AJ, Nishitani $M$, et al.: Finding of agr phase variants in Staphylococcus aureus. mBio. 2019; 10(4): e00796-19. PubMed Abstract | Publisher Full Text | Free Full Text

34. Flannagan R, Heit B, Heinrichs D: Antimicrobial Mechanisms of Macrophages and the Immune Evasion Strategies of Staphylococcus aureus. Pathogens. 2015; 4(4): 826-868

PubMed Abstract | Publisher Full Text | Free Full Text 


\section{Open Peer Review}

\section{Current Peer Review Status:}

\section{Version 1}

Reviewer Report 23 February 2021

https://doi.org/10.21956/wellcomeopenres.17782.r42337

(C) 2021 Unnikrishnan M. This is an open access peer review report distributed under the terms of the Creative Commons Attribution License, which permits unrestricted use, distribution, and reproduction in any medium, provided the original work is properly cited.

\section{Meera Unnikrishnan \\ Division of Biomedical Sciences, University of Warwick, Coventry, UK}

This is a clearly written manuscript, investigating the role of the $S$. aureus lipase 1 and 2 in bacterial killing in whole blood, neutrophils and macrophages. This work is important as lipases are generally considered to impact innate cell functions, although effects on bacterial killing have not been directly assessed yet.

In general experiments have been done well, and the main conclusions are valid. However a few technical clarifications are required.

For the macrophage internalisation assays, when following bacterial replication by CFU, usually it is good to look at an earlier time point as by $24 \mathrm{~h}$ there can be significant cell lysis induced by the WT. Have the authors checked the morphologies or the states of the macrophages during their experiments?

The bacterial 'escape' measurements from macrophages need some clarification. It is not clear if after the $1 \mathrm{~h}$ infection the macrophages were treated with gentamicin to kill all the extracellular bacteria first prior to adding the antibiotic-free medium. This is essential to do in order to measure the escape of intracellular bacteria. It is also not clear if escape was quantified from the culture supernatants or from the the cell lysates. Quantifying bacterial escape is quite tricky, and should be preferably done at multiple time points after infection to get a clear picture. Counting from supernatants are not accurate as most bacteria settle down to the well by $24 \mathrm{~h}$ forming microcolonies, and by $24 \mathrm{~h}$ there is substantial cell lysis, so hard to deduce the 'escaped' population by measuring intracellular counts (by cell lysis). Finally, the authors may want to comment on why the 'escape' numbers are so high between the THP1 vs the primary cells.

Is the work clearly and accurately presented and does it cite the current literature? Yes

Is the study design appropriate and is the work technically sound? 
Partly

Are sufficient details of methods and analysis provided to allow replication by others? Partly

If applicable, is the statistical analysis and its interpretation appropriate? Yes

Are all the source data underlying the results available to ensure full reproducibility? No source data required

Are the conclusions drawn adequately supported by the results? Yes

Competing Interests: No competing interests were disclosed.

Reviewer Expertise: Host pathogen interactions: Intracellular S. aureus infections, Type VII secretion systems, C. difficile colonisation

I confirm that I have read this submission and believe that I have an appropriate level of expertise to confirm that it is of an acceptable scientific standard, however I have significant reservations, as outlined above.

Author Response 30 Mar 2021

J Ross Fitzgerald, The Roslin Institute, Edinburgh, UK

We would firstly like to thank you for your supportive comments regarding our manuscript and for your constructive review. Please find below the response to your individual questions below:

For the macrophage internalisation assays, when following bacterial replication by CFU, usually it is good to look at an earlier time point as by $24 \mathrm{~h}$ there can be significant cell lysis induced by the WT. Have the authors checked the morphologies or the states of the macrophages during their experiments?

At each time point, the macrophages were inspected under a light microscope. Indeed, after 24 hours of $S$. aureus intracellular survival, the macrophages appeared to be in an activated state based on their morphology but without significant cell lysis. Their phenotype was not dissimilar to observations of cell morphology at earlier time points in the experiment.

The bacterial 'escape' measurements from macrophages need some clarification. It is not clear if after the $1 \mathrm{~h}$ infection the macrophages were treated with gentamicin to kill all the extracellular bacteria first prior to adding the antibiotic-free medium. This is essential to do in order to measure the escape of intracellular bacteria. It is also not clear if escape was quantified from the culture supernatants or from the the cell lysates. Quantifying bacterial escape is quite tricky, and 
should be preferably done at multiple time points after infection to get a clear picture. Counting from supernatants are not accurate as most bacteria settle down to the well by $24 \mathrm{~h}$ forming microcolonies, and by $24 \mathrm{~h}$ there is substantial cell lysis, so hard to deduce the 'escaped' population by measuring intracellular counts (by cell lysis).

For measuring $S$. aureus escape we followed the procedure outlined in the schematic shown in Figure 3a. Cells were infected for 1 hour at an MOI of 1 followed by treatment with 100 $\mu \mathrm{g} / \mathrm{ml}$ of gentamycin for 30 minutes to kill any extracellular bacteria. The cells were washed and then subsequently left for $24 \mathrm{~h}$ in a low concentration of gentamycin $(20 \mu \mathrm{g} / \mathrm{ml})$ which does not penetrate the cells, however, was sufficient for killing any bacteria which had escaped due to cell lysis in this time. After 24 hours, the cells were washed again to remove any residual gentamycin and incubated in the antibiotic-free media for the 24 hour "escape" period. In preliminary data not shown, we analysed bacterial escape over a range of time points (ranging from 3-24 hours post removal of gentamycin media) and observed no differences in the recovered viable CFU in the presence and absence of lipase, and thus 24 hours was chosen as a representative time point. To quantify escape, $0.1 \%$ (v/v) TritonX-100 was added on top of both the supernatant and the cells (at a 1:1 ratio). Both micro-colonies and substantial cell lysis was observed and thus wells were scraped to incorporate both the supernatant and lysate for escape CFU quantification.

Finally, the authors may want to comment on why the 'escape' numbers are so high between the THP1 vs the primary cells.

There are multiple potential reasons why there was variation between the recovered escape CFU from primary and the THP1 macrophages. Importantly, considerable differences exist between the immortalised THP1 macrophage cell-line and the primary macrophages. For example, a broader repertoire of chemokine and cytokine responses in primary macrophages could contribute to more efficient killing by the primary cells and thus lower viable recovered CFU.

Competing Interests: No competing interests were disclosed.

Reviewer Report 08 February 2021

https://doi.org/10.21956/wellcomeopenres.17782.r42336

(C) 2021 Morrissey J. This is an open access peer review report distributed under the terms of the Creative Commons Attribution License, which permits unrestricted use, distribution, and reproduction in any medium, provided the original work is properly cited.

\section{Julie A. Morrissey}

Department of Genetics and Genome Biology, University of Leicester, Leicester, UK

This is a very clearly written interesting and relevant article on the role of two Staphylococcus aureus lipases that are secreted into the extracellular milieu. Previous studies have suggested that 
these lipases may interfere with the function of innate immune cells but no previous articles have investigated the direct role of the lipases. This article describes the phenotypic analysis of a $S$. aureus double lipase mutant and recombinant lipase proteins. There were no differences in the survival between the wild type and mutant strains with human whole blood or neutrophils and no effect on phagocytosis, intracellular survival, or escape from both human primary and immortalised cell line macrophages. Therefore, it was concluded that $S$. aureus lipases do not inhibit bacterial killing mechanisms of human macrophages, neutrophils, or whole blood. The article gives a very clear background of the literature of $S$. aureus lipases in innate immunity. The study design is logical and uses a series of well-established phenotypic assays that are well described and use appropriate controls and are shown to be statistically reproducible. There are no major issues to address.

Is the work clearly and accurately presented and does it cite the current literature? Yes

Is the study design appropriate and is the work technically sound?

Yes

Are sufficient details of methods and analysis provided to allow replication by others? Yes

If applicable, is the statistical analysis and its interpretation appropriate? Yes

Are all the source data underlying the results available to ensure full reproducibility? Yes

Are the conclusions drawn adequately supported by the results?

Yes

Competing Interests: No competing interests were disclosed.

Reviewer Expertise: Staphylococcus aureus, pathogenesis, host-microbe interactions

I confirm that I have read this submission and believe that I have an appropriate level of expertise to confirm that it is of an acceptable scientific standard.

Reviewer Report 23 December 2020

https://doi.org/10.21956/wellcomeopenres.17782.r41781

(c) 2020 Alonzo III F. This is an open access peer review report distributed under the terms of the Creative Commons Attribution License, which permits unrestricted use, distribution, and reproduction in any medium, provided the original work is properly cited.

Francis Alonzo III 
Department of Microbiology and Immunology, Stritch School of Medicine, Loyola University Chicago, Maywood, IL, USA

In this Research Article, Sargison et al. test if the S. aureus secreted lipases, Lip1 and Lip2, interfere with the phagocytic killing mechanisms of innate immune cells. Prior work had suggested there might be potential effects on immune cell phagocytosis/killing on account of morphological changes that occurred after the treatment of granulocytes with lipases. Additional work has also demonstrated a role for lipases in interference with immune signaling on account of lipolysis of the lipopeptide ligands of TLR2. No studies to date have directly tested the role of lipases in phagocytic killing or escape from innate immune cells. The authors use a series of well-executed in vitro survival assays with whole blood, primary human neutrophils, monocyte-derived macrophages, and THP-1 differentiated macrophages to monitor the survival of WT S. aureus and an isogenic lip1/lip2 deletion mutant +/- recombinant Lip1/Lip2 over time. They find that lipases do not have a discernable effect on phagocytic killing or bacterial escape in the assays used. The methods contain sufficient detail, and the results are clear and unambiguous. Incidentally, the work also closely resembles unpublished observations made in our lab with murine neutrophils and macrophages, thus the data are further bolstered by similar outcomes among multiple groups. Overall, this work provides important information related to the roles of lipases in hostmicrobe interactions. I have no substantive criticism of this solid study.

Is the work clearly and accurately presented and does it cite the current literature? Yes

Is the study design appropriate and is the work technically sound? Yes

Are sufficient details of methods and analysis provided to allow replication by others? Yes

If applicable, is the statistical analysis and its interpretation appropriate? Yes

Are all the source data underlying the results available to ensure full reproducibility? No source data required

Are the conclusions drawn adequately supported by the results? Yes

Competing Interests: No competing interests were disclosed.

Reviewer Expertise: S. aureus pathogensis, host-microbe interactions, immune response to infection.

I confirm that I have read this submission and believe that I have an appropriate level of expertise to confirm that it is of an acceptable scientific standard. 